\title{
NIM811 downregulates transforming growth factor- $\beta$ signal transduction in vivo and in vitro
}

\author{
JING CHEN $^{1,2^{*}}$, DIAN-GANG LIU ${ }^{3 *}$, HUI WANG ${ }^{1}$, XIAO-NING WU ${ }^{1}$, \\ MIN CONG ${ }^{1}$, HONG YOU ${ }^{1}$ and JI-DONG JIA ${ }^{1}$ \\ ${ }^{1}$ Liver Research Center, Beijing Friendship Hospital, Capital Medical University, Beijing 100050; \\ ${ }^{2}$ Department of Gastroenterology, The Second Affiliated Hospital of Harbin Medical University, \\ Harbin, Heilongjiang 150081; ${ }^{3}$ Department of General Surgery, Xuanwu Hospital, \\ Capital Medical University, Beijing 100053, P.R. China
}

Received November 30, 2014; Accepted September 16, 2015

DOI: $10.3892 / \mathrm{mmr} .2015 .4572$

\begin{abstract}
Liver fibrosis is the common histological feature of a number of chronic liver diseases, and leads to cirrhosis and hepatocellular carcinoma (HCC). It has been demonstrated that N-methyl-4-isoleucine cyclosporine (NIM811) attenuates $\mathrm{CCl}_{4}$-induced liver fibrosis and inflammation in rats. The present study investigated whether NIM811 downregulated transforming growth factor (TGF) $\beta$ signaling in rats with $\mathrm{CCl}_{4}$-induced liver fibrosis and in HSC-T6 cells. Liver tissues were obtained from rats with $\mathrm{CCl}_{4}$-induced liver fibrosis, with or without NIM811 treatment. HSC-T6 cells were cultured with or without NIM811 for $18 \mathrm{~h}$ under serum-free conditions. Expression of collagen I, $\alpha$-smooth muscle actin ( $\alpha$-SMA), TGF- $\beta 1$, TGF- $\beta$ receptor I (T $\beta$ R-I) and TGF- $\beta$ pathway downstream signaling molecules were measured by reverse transcription-quantitative polymerase chain reaction and/or western blotting. Collagen I and TGF- $\beta 1$ content in the cell supernatant was measured by ELISA. NIM811 profoundly inhibited collagen I, $\alpha$-SMA, TGF- $\beta 1$ and T $\beta R$-I expression in the liver of $\mathrm{CCl}_{4}$-treated rats. Phosphorylation of Smad2, 3 and 1/5/8 was decreased in the liver of NIM811-treated groups, accompanied by increased In addition, $\mathrm{Smad} 7$ expression compared with the $\mathrm{CCl}_{4}$-treated rats. NIM811 inhibited collagen I, TGF- $\beta 1$ and T $\beta$ R-I expression in HSC-T6 cells. Smad1 mRNA and phospho-Smad1/5/8
\end{abstract}

Correspondence to: Dr Ji-Dong Jia, Liver Research Center, Beijing Friendship Hospital, Capital Medical University, 95 Yong-An Road, Beijing 100050, P.R. China

E-mail: jiamd@263.net

*Contributed equally

Abbreviations: TGF- $\beta$, transforming growth factor- $\beta$; HSC, hepatic stellate cell; SMA, $\alpha$-smooth muscle actin

Key words: carbon tetrachloride, N-methyl-4-isoleucine cyclosporine, hepatic fibrosis, transforming growth factor- $\beta$ protein levels decreased following NIM811 treatment, accompanied by increased Smad7 expression in HSC-T6 cells compared with normal controls. Furthermore, NIM811 also inhibited collagen I mRNA expression in the liver of rats with $\mathrm{CCl}_{4}$-induced liver fibrosis and in HSC-T6 cells. The results suggest that the antifibrotic effect of NIM811 was due to the inhibition of TGF- $\beta 1$ and its downstream signaling molecules.

\section{Introduction}

Liver fibrosis is a reversible wound-healing response that is characterized by increased and altered deposition of extracellular matrix (ECM) in the liver (1). This process is rigorously controlled by several growth factors and cytokines (2-5). Of these, transforming growth factor (TGF) $\beta$ is the most potent factor in stimulating type I collagen gene transcription, which is the predominant ECM component of fibrotic tissue (6).

$\mathrm{N}$-methyl-4-isoleucine cyclosporine (NIM811) is a derivative of cyclosporine, but does not exhibit an immunosuppressive effect. NIM811 inhibits the expression of the mitochondrial permeability transition $(\mathrm{mPT})$ pore protein in hepatocytes, which results in hepatocyte cytoprotection (7-10). It also suppresses hepatic stellate cell (HSC) proliferation and collagen production, as well as stimulating collagenase activity in vitro (11). These findings indicate that NIM811 is a potential candidate for antifibrosis therapy. Indeed, it was found previously that NIM811 attenuates liver fibrosis and inflammation in rats with $\mathrm{CCl}_{4}$-induced liver fibrosis (12). Therefore, in the present study, the TGF- $\beta$ signaling pathway was analyzed with the aim of elucidating the molecular mechanism underlying the effects of NIM811 in rats with $\mathrm{CCl}_{4}$-induced liver fibrosis and cultured HSC-T6 cells.

\section{Materials and methods}

Animal study. Liver samples were obtained from control rats and rats with $\mathrm{CCl}_{4}$-induced liver fibrosis, with or without NIM811 treatment. These liver samples were collected by Dr Hui Wang. NIM811 was a gift from Novartis (Basel, Switzerland). Male Wistar rats weighing 230-260 g were obtained from Beijing Vital River Laboratory Animal 
Table I. Primers for reverse transcription-quantitative PCR analysis.

\begin{tabular}{|c|c|c|c|}
\hline Gene & Primer sequence & Product size (bp) & Accession number \\
\hline GAPDH & $\begin{array}{l}\text { F: 5'-CCTGCCAAGTATGATGACATCAAGA3' } \\
\text { R: 5'-GTAGCCCAGGATGCCCTTTAGT3' }\end{array}$ & 75 & ВС059110.1 \\
\hline Col I & $\begin{array}{l}\text { F: 5'-CCTTTCTCCACCCCCTCTT-3' } \\
\text { R: 5'-TGTGTCTTTGGGGGAGACTT -3' }\end{array}$ & 69 & NM_053304.1 \\
\hline$\alpha-\mathrm{SMA}$ & $\begin{array}{l}\text { F: 5'-TGCCATGTATGTGGCTATTCA-3' } \\
\text { R: 5'-ACCAGTTGTACGTCCAGAAGC-3 }\end{array}$ & 61 & NM_001613.2 \\
\hline TGF- $\beta 1$ & $\begin{array}{l}\text { F: 5'-CCTGGAAAGGGCTCAACAC-3' } \\
\text { R: 5'-CTGCCGTACACAGCAGTTCT-3' }\end{array}$ & 100 & NM_021578.2 \\
\hline $\mathrm{T} \beta \mathrm{R}-\mathrm{I}$ & $\begin{array}{l}\text { F: 5'-CACGATGAGCTGAGCCTGTA-3' } \\
\text { R: 5'-ACCCTGGAGTGCATGGTAAG-3' }\end{array}$ & 60 & NM_012775.2 \\
\hline Smad1 & $\begin{array}{l}\text { F: 5'-AGAAAGGGGCCATGGAAG-3' } \\
\text { R:5'-AGCGAGGAATGGTGACACA-3' }\end{array}$ & 78 & NM_013130.2 \\
\hline Smad7 & $\begin{array}{l}\text { F: 5'-GGAGTCCTTTCCTCTCTC -3' } \\
\text { R: 5'-GGCTCAATGAGCATGCTCAC -3' }\end{array}$ & 73 & NM_030858.1 \\
\hline Id1 & $\begin{array}{l}\text { F: 5'-GCGAGATCAGTGCCTTGG-3' } \\
\text { R: 5'-TTTTCCTCTTGCCTCCTGAA-3' }\end{array}$ & 123 & NM_012797.2 \\
\hline
\end{tabular}

PCR, polymerase chain reaction; GAPDH, glyceraldehyde 3-phosphate dehydrogenase; Col I, collagen I; $\alpha$-SMA, $\alpha$-smooth muscle actin; TGF, transforming growth factor; T $\beta$ R-I, TGF- $\beta$-receptor I.

Technology Co., Ltd. (Beijing, China). Liver fibrosis was induced by intraperitoneal injection of $0.2 \mathrm{ml} / 100 \mathrm{~g}$ body weight of $40 \% \mathrm{CCl}_{4} /$ corn oil twice weekly. Rats were also treated with different doses of NIM811 (low dose, $10 \mathrm{mg} / \mathrm{kg} / \mathrm{day}$; and high dose, $20 \mathrm{mg} / \mathrm{kg} /$ day) by gavage for 6 weeks as previously reported (13). All protocols and procedures were approved by the Animal Care and Use Committee of Capital Medical University (Beijing, China). The animals were housed in an air-conditioned room at $23-25^{\circ} \mathrm{C}$ with a $12 \mathrm{~h}$ dark/light cycle for 1 week prior to initiation of the experiment. All animals received humane care during the study with unlimited access to chow and water.

Cell culture. The HSC-T6 cell line was provided by Dr Scott L. Friedman (Mount Sinai School of Medicine, New York, NY, USA) and was cultured in Dulbecco's modified Eagle's medium (DMEM; Invitrogen Life Technologies, Carlsbad, CA, USA) with $10 \%$ fetal calf serum (FCS; Gibco Life Technologies, Carlsbad, CA, USA). The cell viability of HSCs was $>90 \%$ at $24 \mathrm{~h}$ in the presence of $2 \mu \mathrm{M}$ NIM811 in DMEM under serum-free conditions, thus concentrations of $0.5,1$ and $2 \mu \mathrm{M}$ were used. After serum starvation for $16 \mathrm{~h}$, HSC-T6 cells were treated with NIM811 $(0.5,1$ or $2 \mu \mathrm{M})$, TGF $\beta 1$ (5 ng/ml) (14) or TGF $\beta 1(5 \mathrm{ng} / \mathrm{ml})$ with NIM811 (0.5, 1 or $2 \mu \mathrm{M})$ in serum-free medium for 6,12 or $18 \mathrm{~h}$.

Determination of collagen I and TGF- $\beta 1$ in HSC-T6 cell supernatant. Cultured HSC-T6 cells were plated into 6-well cell culture plates at a density of $10^{5}$ cells/well and were incubated in serum-free medium with $0,0.5,1$ or $2 \mu \mathrm{M}$ NIM811 for $18 \mathrm{~h}$. Collagen I and TGF- $\beta 1$ production was determined in the culture medium using an ELISA (USCN Life Science Inc., Wuhan, China) and immunoassay kit (R\&D Systems, Minneapolis, MN, USA), respectively.
mRNA levels of collagen I, $\alpha$-smooth muscle actin (SMA), TGF- $\beta 1$ and TGF- $\beta$ pathway downstream signaling moleculedetection by reverse transcription-quantitative polymerase chain reaction ( $R T-q P C R)$. Total RNA was extracted from snap-frozen rat liver specimens and HSC-T6 cells using TRIzol reagent (Invitrogen Life Technologies). The amount of RNA was quantified, and its quality was verified by ultraviolet absorbance spectrophotometry at 260 and $280 \mathrm{~nm}$ (BioPhotometer ${ }^{\circledR}$ D30; Eppendorf North America Inc., Hauppauge, NY, USA). cDNA was reversed transcribed using the High-Capacity cDNA Reverse Transcription kit (Applied Biosystems, Foster City, CA, USA), according to the manufacturer's instructions. The reaction conditions were as follows: $25^{\circ} \mathrm{C}$ for $10 \mathrm{~min}, 37^{\circ} \mathrm{C}$ for $150 \mathrm{~min}, 85^{\circ} \mathrm{C}$ for $5 \mathrm{sec}$, and $4^{\circ} \mathrm{C}$ for $5 \mathrm{~min}$, prior to chilling on ice. cDNA was stored at $-20^{\circ} \mathrm{C}$ for future use.

Collagen I, $\alpha$-SMA, TGF- $\beta 1$, T $\beta$ R-I, Smad1, Smad7 and Id1 mRNA levels were quantified by RT-qPCR. The sequences of the primers used are shown in Table I. GAPDH, a housekeeping gene, was used as an internal control primer for target genes. All primers were obtained from Invitrogen Life Technologies (Beijing, China). The expression of mRNA was measured by SYBR Green real-time PCR using an ABI 7500 instrument (Applied Biosystems). PCR was performed in $20 \mu \mathrm{l}$ buffer that contained $2 \mu \mathrm{g}$ cDNA, $1 \mu \mathrm{l}$ each primer, and $10 \mu \mathrm{l}$ SYBR Green PCR Master mix (Applied Biosystems). Comparative cycle quantification $(\mathrm{Cq})$ calculations were all relative to the control group. The expression of mRNA relative to the control was derived using the equation $2^{-\Delta \Delta \mathrm{Cq}}$.

Protein detection of $\alpha$-SMA, T $\beta R-I$ and TGF- $\beta$ pathway downstream signaling molecules by western blotting. Protein was extracted from liver samples and HSC-T6 cells using a Protein Extractor IV (DBI, Shanghai, China), homogenized, 
Table II. Level of mRNA expression in rat liver in 6 weeks.

\begin{tabular}{|c|c|c|c|c|}
\hline mRNA & Normal $(n=7)$ & $\mathrm{CCl}_{4}(\mathrm{n}=8)$ & NIM811 $(10 \mathrm{mg} / \mathrm{kg})(\mathrm{n}=6)$ & $\operatorname{NIM} 811(20 \mathrm{mg} / \mathrm{kg})(\mathrm{n}=7)$ \\
\hline Col I & $1.0 \pm 0.4$ & $92.0 \pm 4.6^{\mathrm{b}}$ & $38.6 \pm 7.8^{\mathrm{a}}$ & $40.9 \pm 2.4^{\mathrm{a}}$ \\
\hline$\alpha-\mathrm{SMA}$ & $1.0 \pm 0.3$ & $60.5 \pm 4.6^{\mathrm{b}}$ & $18.3 \pm 2.2^{\mathrm{a}}$ & $16.3 \pm 3.0^{\mathrm{a}}$ \\
\hline TGF- $\beta 1$ & $1.0 \pm 0.1$ & $8.6 \pm 0.2^{b}$ & $3.0 \pm 0.6^{\mathrm{a}}$ & $3.4 \pm 0.5^{\mathrm{a}}$ \\
\hline $\mathrm{T} \beta \mathrm{R}-\mathrm{I}$ & $1.0 \pm 0.2$ & $1.9 \pm 0.3^{\mathrm{b}}$ & $1.0 \pm 0.2^{\mathrm{a}}$ & $0.9 \pm 0.2^{\mathrm{a}}$ \\
\hline Id1 & $1.0 \pm 0.4$ & $2.9 \pm 0.2^{\mathrm{b}}$ & $1.0 \pm 0.2^{\mathrm{a}}$ & $1.1 \pm 0.2^{\mathrm{a}}$ \\
\hline Smad1 & $1.0 \pm 0.3$ & $2.1 \pm 0.1^{\mathrm{b}}$ & $1.5 \pm 0.2^{\mathrm{a}}$ & $1.2 \pm 0.3^{\mathrm{a}}$ \\
\hline Smad2 & $1.0 \pm 0.2$ & $2.9 \pm 0.3^{\mathrm{b}}$ & $1.6 \pm 0.2^{\mathrm{a}}$ & $1.2 \pm 0.4^{\mathrm{a}}$ \\
\hline Smad7 & $1.0 \pm 0.1$ & $1.9 \pm 0.2^{\mathrm{b}}$ & $2.7 \pm 0.3^{\mathrm{a}}$ & $3.7 \pm 0.3^{\mathrm{a}}$ \\
\hline
\end{tabular}

Data are normalized to glyceraldehyde 3-phosphate dehydrogenase and expressed as the mean \pm standard deviation. ${ }^{\text {a }}<0.01$ vs. the $\mathrm{CCl}{ }_{4}$ group; ${ }^{\mathrm{b}} \mathrm{P}<0.01$ vs. the normal group. NIM811, N-methyl-4-isoleucine cyclosporine; Col I, collagen I; $\alpha$-SMA, smooth muscle actin; TGF, transforming growth factor; T $\beta$ R-I, TGF- $\beta$-receptor I.

and assayed using a Pierce BCA Protein Assay kit (Thermo Fisher Scientific Inc., Rockford, IL, USA). Protein samples $(40 \mu \mathrm{g})$ were subjected to SDS-PAGE (80 V for $40 \mathrm{~min}$ on a $5 \%$ acrylamide stacking gel and $120 \mathrm{~V}$ for 70 min on a 10 or $15 \%$ running gel), and then transferred (390 MA for $70 \mathrm{~min}$ or $80 \mathrm{~V}$ for $120 \mathrm{~min}$ ) to a nitrocellulose membrane (Hybond-C Extra Membrane 45; Amersham Biosciences, Uppsala, Sweden). The membranes were soaked in Tris-buffered saline (10 mmol/1 Tris- $\mathrm{HCl}$ and $250 \mathrm{~mol} / \mathrm{l} \mathrm{NaCl}$ ) that contained $5 \%$ non-fat powdered milk and 0.1\% Tween-20 (Santa Cruz Biotechnology, Inc., Santa Cruz, CA, USA) for $2 \mathrm{~h}$ to block non-specific sites. They were then incubated with primary antibody overnight at $4^{\circ} \mathrm{C}$ in blocking solution. Antibody dilutions were as follows: Rabbit anti-rat T $\beta$ R-I (sc-9048) and Id1 (sc-488) polyclonal antibodies (1:1,000; Santa Cruz Biotechnology Inc.); monoclonal mouse anti-rat $\alpha$-SMA (SAB5500002) and $\beta$-actin (SAB1403520) antibodies (1:1,000, 1:10,000; Sigma-Aldrich, St. Louis, MO, USA); monoclonal rabbit anti-rat phosph-Smad2 (\#3108), phosph-Smad3 (\#9520) and phosph-Smad1/5/8 (\#13820) antibodies (1:500, Cell Signaling Technology Inc., Beverly, MA, USA); polyclonal rabbit anti-rat Smad7 antibodies (PA1-41506; 1:1,000; Invitrogen Life Technologies); and horseradish peroxidase (HRP)-linked anti-rabbit (ZDR-5306) or anti-mouse (ZDR-5307) IgG secondary antibodies (1:10,000; Beijing Zhongshan Golden Bridge Biotechnology Co., Ltd., Beijing, China). The resultant blots were washed and incubated with HRP-linked goat anti-rabbit IgG secondary antibody for $2 \mathrm{~h}$ at room temperature. Immunoreactivity was visualized using an enhanced chemiluminescence kit (Thermo Fisher Scientific Inc.). Films (Kodak, Beijing, China) were scanned using the Bio-Rad imaging system. Protein expression levels were normalized to $\beta$-actin.

Statistical analysis. The results are expressed as the mean \pm standard deviation. Statistical analysis was performed using one-way analysis of variance and unpaired Student's $\mathrm{t}$-test as appropriate. $\mathrm{P}<0.05$ was considered to indicate a statistically significant difference. Statistical analyses were performed using SPSS version 17.0 (SPSS Inc., Chicago, IL, USA).
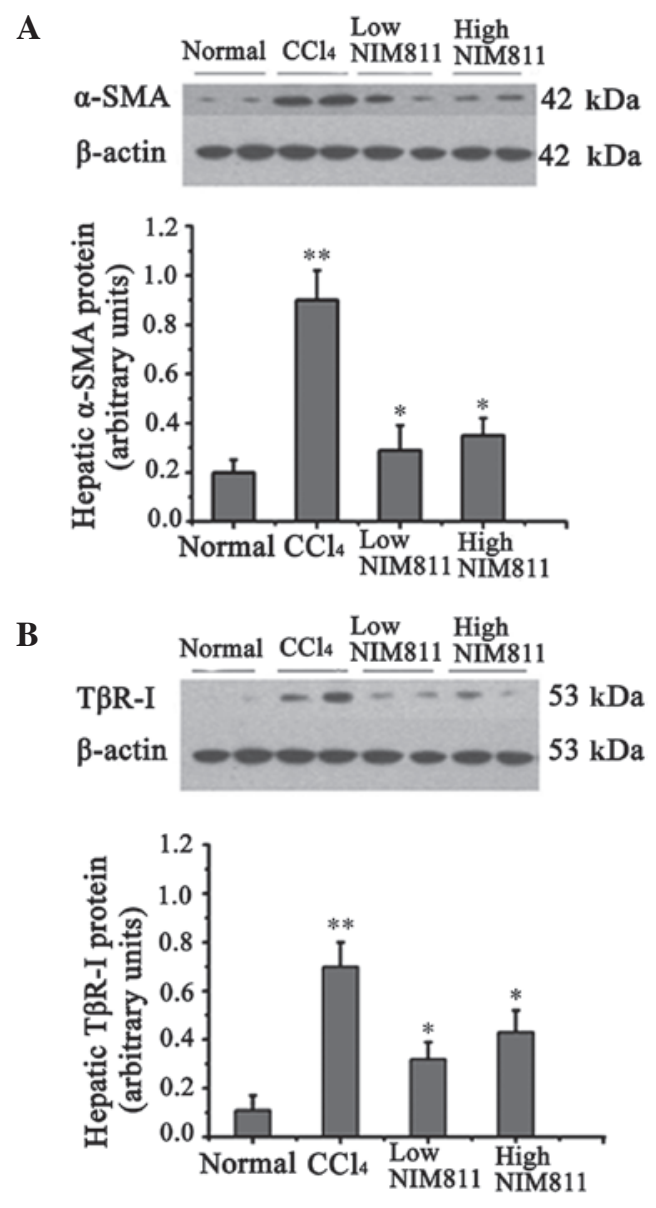

Figure 1. Protein expression of (A) $\alpha$-SMA and (B) T $\beta R-I$ in the liver was determined by western blotting in normal, $\mathrm{CCl}_{4}$-treated and NIM811-treated rats. Data are normalized to the internal control ( $\beta$-actin) and expressed as the mean \pm standard deviation. ${ }^{*} \mathrm{P}<0.01$ vs. the $\mathrm{CCl}_{4}$ group; ${ }^{* *} \mathrm{P}<0.01$ vs. the normal group, $n=7$. NIM811, N-methyl-4-isoleucine cyclosporine; $\alpha$-SMA, smooth muscle actin; T $\beta$ R-I, TGF- $\beta$-receptor I.

\section{Results}

Effect of NIM811 on collagen I, $\alpha-S M A, T G F-\beta 1$ and T $\beta R-I$ expression in rats. RT-qPCR analysis showed that after treat- 
Table III. Col I mRNA expression in the HSC-T6 cell line with NIM811 treatment after 6, 12 and $18 \mathrm{~h}$.

Col I expression following NIM811 $(\mu \mathrm{M})$ treatment

Incubation time $(\mathrm{h})$

\begin{tabular}{cccc}
\hline 0 & 0.5 & 1 & 2 \\
$1.00 \pm 0.05$ & $0.95 \pm 0.09$ & $0.89 \pm 0.05^{\mathrm{a}}$ & $0.82 \pm 0.05^{\mathrm{a}}$ \\
$1.00 \pm 0.06$ & $0.92 \pm 0.06^{\mathrm{a}}$ & $0.84 \pm 0.07^{\mathrm{a}}$ & $0.76 \pm 0.08^{\mathrm{a}}$ \\
$1.00 \pm 0.08$ & $0.90 \pm 0.04^{\mathrm{a}}$ & $0.75 \pm 0.06^{\mathrm{a}}$ & $0.64 \pm 0.05^{\mathrm{a}}$
\end{tabular}

Data are normalized to glyceraldehyde 3-phosphate dehydrogenase and expressed as the mean \pm standard deviation. ${ }^{\mathrm{a}} \mathrm{P}<0.05$ vs. the normal control $(0 \mu \mathrm{m})$. NIM811, N-methyl-4-isoleucine cyclosporine; Col I, collagen I.
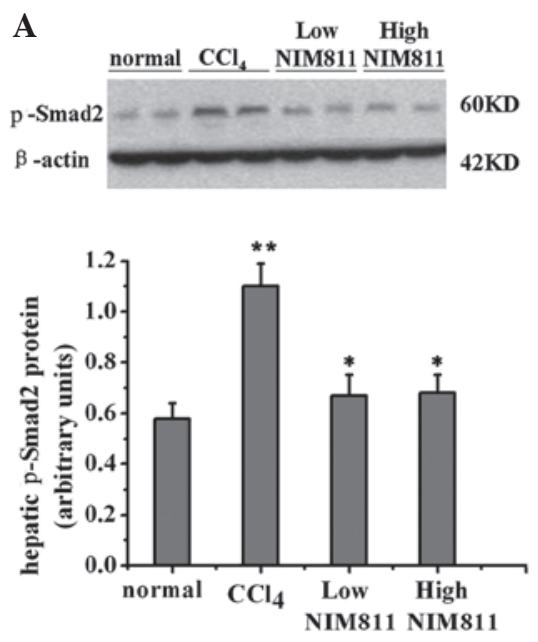
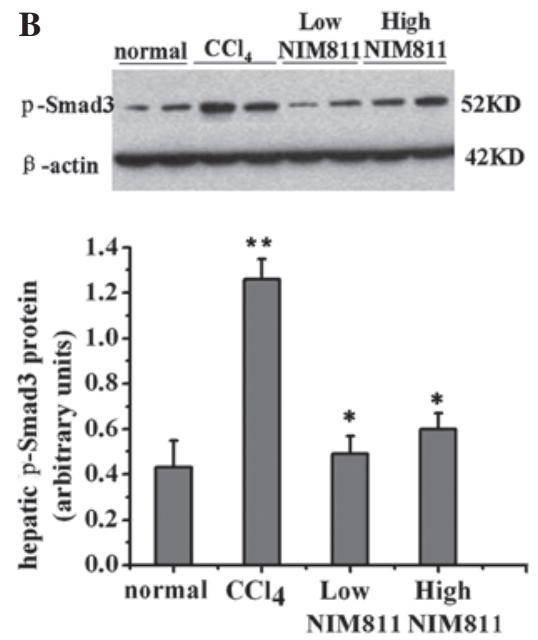
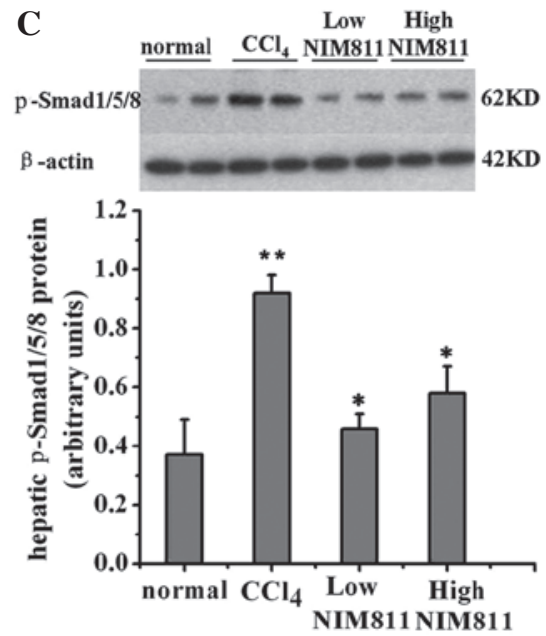

$\mathbf{D}$
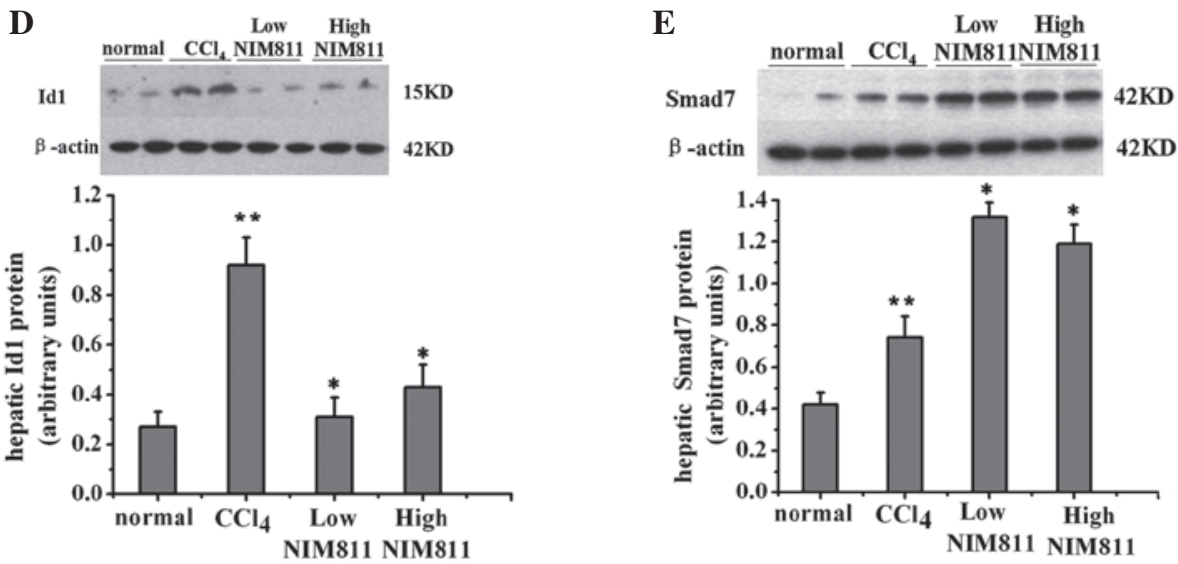

Figure 2. Protein expression of (A) p-Smad2, (B) p-Smad3, (C) p-Smad1/5/8, (D) Smad7 and (E) Id1 in the liver was determined by western blotting in normal, $\mathrm{CCl}_{4}$-treated and NIM811-treated rats. Data are normalized to internal control $\left(\beta\right.$-actin) and expressed as the mean \pm standard deviation. ${ }^{*} \mathrm{P}<0.01 \mathrm{vs}$. the $\mathrm{CCl}_{4}$ group; ${ }^{* *} \mathrm{P}<0.01$ vs. the normal group. p-Smad2, p-Smad3, p-Smad1/5/8 and Id1 proteins increased after treatment with CCl ${ }_{4}$, and decreased in NIM811-treated rats. Smad7 increased in rats with liver fibrosis and further increased in NIM811-treated rats. NIM811, N-methyl-4-isoleucine cyclosporine.

ment with $\mathrm{CCl}_{4}$ for 6 weeks, collagen I mRNA expression increased compared with that in normal rats, whereas NIM811 inhibited the expression significantly (10 and $20 \mathrm{mg} / \mathrm{kg}$, respectively; $\mathrm{P}<0.01$; Table II).

$\alpha$-SMA mRNA expression in rats with liver fibrosis was significantly increased compared with that in the normal controls, and decreased significantly in the two NIM811-treated groups $(\mathrm{P}<0.01)$ (Table II). In the liver of rats with $\mathrm{CCl}_{4}$-induced liver fibrosis, $\alpha$-SMA protein expression increased significantly compared with normal rats, whereas its expression was inhibited by NIM811 treatment (Fig. 1A).

The level of TGF- $\beta 1$ and T $\beta$ R-I mRNA increased after $\mathrm{CCl}_{4}$ injection for 6 weeks and was blocked by NIM811 treatment (Table II). Similar to mRNA expression, T $\beta$ R-I protein was also reduced in the liver of NIM811-treated rats compared with rats with $\mathrm{CCl}_{4}$-induced liver fibrosis (Fig. 1B). These results indicate that NIM811 inhibited liver fibrosis through the TGF- $\beta$ pathway. 
Table IV. mRNA expression in HSC-T6 cells following treatment with TGF- $\beta 1$, NIM811 or a combination of the two.

\begin{tabular}{lcccc}
\hline mRNA & Normal & TGF- $\beta 1(5 \mathrm{ng} / \mathrm{ml})$ & NIM811 $(2 \mu \mathrm{M})$ & TGF- $\beta 1+$ NIM811 \\
\hline Col I & $1.00 \pm 0.05$ & $1.78 \pm 0.08^{\mathrm{a}}$ & $0.64 \pm 0.05^{\mathrm{a}}$ & $0.66 \pm 0.10^{\mathrm{a}}$ \\
$\alpha$-SMA & $1.00 \pm 0.04$ & $2.34 \pm 0.15^{\mathrm{a}}$ & $1.46 \pm 0.09^{\mathrm{a}}$ & $1.44 \pm 0.06^{\mathrm{a}}$ \\
T $\beta$ R-I & $1.00 \pm 0.05$ & $1.18 \pm 0.09^{\mathrm{a}}$ & $0.56 \pm 0.08^{\mathrm{a}}$ & $0.60 \pm 0.11^{\mathrm{a}}$ \\
Smad1 & $1.00 \pm 0.09$ & $1.78 \pm 0.13^{\mathrm{a}}$ & $0.68 \pm 0.06^{\mathrm{a}}$ & $0.72 \pm 0.14^{\mathrm{a}}$ \\
Id1 & $1.00 \pm 0.06$ & $1.46 \pm 0.10^{\mathrm{a}}$ & $0.58 \pm 0.05^{\mathrm{a}}$ & $0.62 \pm 0.08^{\mathrm{a}}$ \\
Smad7 & $1.00 \pm 0.04$ & $1.05 \pm 0.10$ & $1.64 \pm 0.14^{\mathrm{a}}$ & $1.48 \pm 0.10^{\mathrm{a}}$ \\
\hline
\end{tabular}

Data are normalized to glyceraldehyde 3-phosphate dehydrogenase and expressed as the mean \pm standard deviation. ${ }^{\text {aP }}<0.05$ vs. the normal control. NIM811, N-methyl-4-isoleucine cyclosporine; TGF- $\beta 1$, transforming growth factor $\beta 1$; Col I, collagen I; $\alpha$-SMA, $\alpha$-smooth muscle actin; T $\beta$ R-I, TGF- $\beta$-receptor I.

Table V. mRNA expression in the HSC-T6 cell line in the presence of NIM811 for $18 \mathrm{~h}$.

\begin{tabular}{lcccc}
\hline & \multicolumn{4}{c}{$\mathrm{NIM} 811(\mu \mathrm{M})$} \\
\cline { 2 - 5 } mRNA & 0 & 0.5 & 1 & 2 \\
\hline TGF- $\beta 1$ & $1.00 \pm 0.06$ & $0.91 \pm 0.05^{\mathrm{a}}$ & $0.72 \pm 0.04^{\mathrm{a}}$ & $0.50 \pm 0.07^{\mathrm{a}}$ \\
T $\beta$ R-I & $1.00 \pm 0.08$ & $0.58 \pm 0.04^{\mathrm{a}}$ & $0.58 \pm 0.06^{\mathrm{a}}$ & $0.57 \pm 0.05^{\mathrm{a}}$ \\
Smad1 & $1.00 \pm 0.09$ & $0.84 \pm 0.04^{\mathrm{a}}$ & $0.72 \pm 0.07^{\mathrm{a}}$ & $0.64 \pm 0.06^{\mathrm{a}}$ \\
Id1 & $1.00 \pm 0.12$ & $0.77 \pm 0.04^{\mathrm{a}}$ & $0.58 \pm 0.06^{\mathrm{a}}$ & $0.44 \pm 0.05^{\mathrm{a}}$ \\
Smad7 & $1.00 \pm 0.09$ & $1.49 \pm 0.10^{\mathrm{a}}$ & $1.57 \pm 0.06^{\mathrm{a}}$ & $1.69 \pm 0.12^{\mathrm{a}}$ \\
\hline
\end{tabular}

Data are normalized to glyceraldehyde 3-phosphate dehydrogenase and expressed as the mean \pm standard deviation. ${ }^{\text {a }} \mathrm{P}<0.05$ vs. the normal control. NIM811, N-methyl-4-isoleucine cyclosporine; TGF- $\beta 1$, transforming growth factor $\beta 1$; T $\beta$ R-I, TGF- $\beta$-receptor I.

$\mathbf{A}$

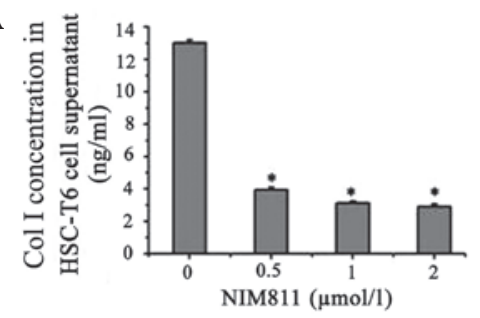

C

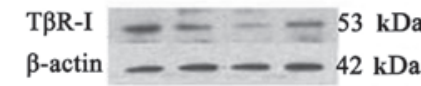

$\mathbf{E}$

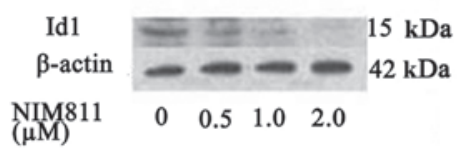

B

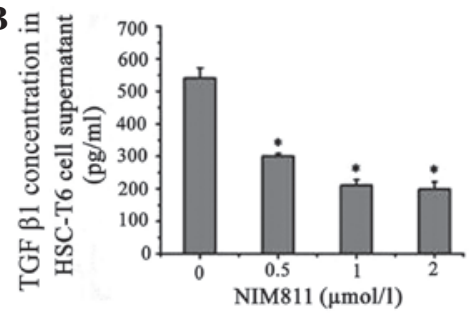

D

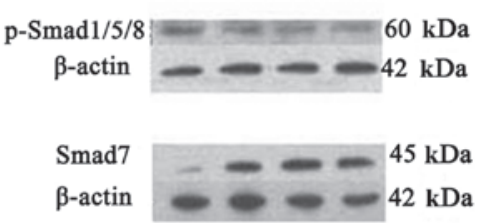

Figure 3. Protein expression of (A) collagen I and (B) TGF- $\beta 1$ in the HSC-T6 cell supernatant was determined by ELISA in normal and NIM811-treated rats. Protein expression of (C) T $\beta R$-I, (D) p-Smad1/5/8, (E) Id1 and (F) Smad7 in HSC-T6 cells was determined by western blotting. Data are normalized to internal control ( $\beta$-actin) and expressed as the mean \pm standard deviation. T $\beta R$-I, p-Smad1/5/8 and Id1 levels decreased in NIM811-treated cells in a concentration-dependent manner and Smad7 levels increased. " $\mathrm{P}<0.01$ vs. $\mathrm{CCl}_{4}$ group. NIM811, N-methyl-4-isoleucine cyclosporine; Col I, collagen I; TGF, transforming growth factor; T $\beta$ R-I, TGF- $\beta$-receptor I.

Effect of NIM811 on TGF-ß/anaplastic lymphoma kinase $(A L K) 5$ and TGF- $\beta / A L K 1$ signaling pathway in rat liver. p-Smad2, p-Smad3, Smad7, p-Smad1/5/8 and Id1 were detected by western blotting. p-Smad2, p-Smad3 and $\mathrm{p}-\mathrm{Smad} 1 / 5 / 8$ protein levels increased following treatment with
$\mathrm{CCl}_{4}$, and decreased in NIM811-treated rats (Fig. 2A-C). The level of Smad7 increased in rats with liver fibrosis and further increased in NIM811-treated rats (Fig. 2D). Id1 is the downstream signaling molecule of the TGF- $\beta /$ ALK $1 / \operatorname{Smad} 1 / 5 / 8$ pathway and was decreased following NIM811 treatment 
(Fig. 2E). Thus, NIM811 downregulated the TGF- $\beta$ pathway in $\mathrm{CCl}_{4}$-treated rats.

Effect of NIM811 on collagen I expression in HSC-T6 cells. To assess the effect of NIM811 on ECM production by HSCs, collagen I mRNA and protein levels were determined in HSCs and culture medium. It was demonstrated that the collagen I mRNA level decreased in the presence of NIM811 compared with normal control HSC-T6 cells $(\mathrm{P}<0.05$; Table III). This effect was most pronounced in the presence of NIM811 after $18 \mathrm{~h}$, thus, $18 \mathrm{~h}$ was selected as the time point for the follow-up experiments. Treatment of the cells with increasing concentrations of NIM811 led to a concentration-dependent suppression of collagen I production; $0.5 \mu \mathrm{M}$ NIM811 reduced collagen I accumulation by $\sim 70 \%$ and $2 \mu \mathrm{M}$ NIM811 reduced collagen I accumulation by $\sim 77 \%$ in HSC-T6 cell supernatant after treatment for $18 \mathrm{~h}$ (Fig. 3A).

Furthermore, the level of collagen I increased after TGF $\beta 1$ treatment and was reduced by NIM811 or TGF $\beta 1$ and NIM811 co-treatment (Table IV).

Effect of NIM811 on TGF- $\beta 1$ and T $\beta R-I$ and TGF- $\beta / A L K 1$ signaling pathway molecules in cultured HSC-T6 cells. It was demonstrated that NIM811 suppressed the expression of TGF- $\beta 1$ and T $\beta$ R-I mRNA in a concentration-dependent manner $(\mathrm{P}<0.05$; Table V). Production of TGF- $\beta 1$ in HSC-T6 cell supernatant was also decreased to $\sim 40 \%$ by $2 \mu \mathrm{M}$ NIM811 treatment $(\mathrm{P}<0.01$; Fig. 3B). It was additionally identified that T $\beta$ R-I protein expression was suppressed by NIM811 $(\mathrm{P}<0.05$; Fig. 3C). It was also found that NIM811 suppressed Smad1 and Id1 transcription, which was accompanied by decreased phosphorylation of Smad1/5/8 and decreased Id1 protein levels (Table V, Fig. 3D and E). Smad7, which acts as an inhibitory Smad, increased following NIM811 treatment (Table V, Fig. 3F).

To determine whether the addition of exogenous TGF- $\beta$ may restore fibrosis in the presence of NIM811, HSC-T6 cells were stimulated with TGF- $\beta$. Results showed that the levels of T $\beta$ R-I, Smad1 and Id1 increased following TGF $\beta 1$ treatment and were reduced by treatment with NIM811 alone or TGF $\beta 1$ in combination with NIM811 (Table IV).

\section{Discussion}

It was demonstrated that NIM811 attenuated collagen type I expression in the liver of rats with $\mathrm{CCl}_{4}$-induced liver fibrosis and cultured HSC-T6 cells. This effect may have been associated with the suppression of TGF- $\beta 1$ and the TGF- $\beta 1$ signaling pathway.

Collagen type I is the predominant constituent of the ECM in fibrotic liver, and its expression is regulated transcriptionally and post-transcriptionally by a number of stimuli and pathways $(15,16)$. TGF- $\beta 1$ is derived from paracrine and autocrine sources, and is the key cytokine in the control of tissue repair. Deregulation of production and degradation of ECM induced by TGF- $\beta 1$ is a cause of liver fibrosis (17). TGF- $\beta 1$ binds to two different serine/threonine kinase receptors, T $\beta R-I$ and T $\beta$ R-II (18). Upon ligand binding, T $\beta$ R-I specifically activates intracellular Smad proteins $(19,20)$, which are a family of bifunctional molecules that are known TGF- $\beta 1$ downstream signals. Following Smad activation, numerous extracellular and intracellular signals converge to fine-tune and enhance the effects of TGF- $\beta 1$ during fibrogenesis $(1,21,22)$. Smad1, 2 and 3 are stimulatory, whereas $\operatorname{Smad} 7$ is inhibitory and is antagonized by Id1 $(23,24)$. Therefore, the TGF- $\beta 1$ signaling pathway, including TGF- $\beta$ /ALK5 and TGF- $\beta$ /ALK1 branches, has an important role in liver fibrogenesis.

TGF- $\beta 1$ signal cascades through Smad2 and Smad3 strongly regulate the expression of the type I collagen gene $(20,25)$. In the present study, decreased liver collagen type I mRNA expression was accompanied by downregulation of phosphorylation of Smad2 and Smad3 in rats with liver fibrosis treated with NIM811. NIM811 also suppressed p-Smad2 and p-Smad3 in HSCs in a previous study, which indicates that NIM811 decreases collagen accumulation through downregulation of TGF- $\beta 1 /$ ALK5/Smad2/3 branch (11).

It was also demonstrated that NIM811 inhibited the protein levels of phospho-Smad1/5/8 and Id 1 in the liver of NIM811-treated rats. Recent research has demonstrated that the TGF- $31 /$ ALK1/Smad1 pathway and its downstream factor Id1 are important in liver fibrosis. Id1 is the helix-loop-helix $(\mathrm{HLH})$ protein inhibitor of differentiation 1, and is hypothesized to affect the balance between cell growth and differentiation by negatively regulating the function of basic HLH transcription factors (26). Recently, Id1 has been found to be a novel TGF- $\beta 1$ target gene in HSCs. Id1 expression and Smad1 phosphorylation are co-induced during hepatic fibrogenesis. The existence of ALK1 and the TGF- $\beta 1 /$ ALK1/Smad1 pathway is crucial during the transdifferentiation of primary rat HSCs to myofibroblasts (23). Activation of the TGF- $\beta 1 /$ ALK1/Smad1 pathway may be enhanced by TGF $\beta 1$ in LX-2 cells (27). Treatment of HSCs with TGF- $\beta 1$ led to increased Id1 protein expression, which was not directly mediated by the ALK5/Smad2/3, but by the ALK1/Smad1 pathway (27).

The two branches of the TGF- $\beta 1$ signaling pathway, TGF- $\beta 1 /$ ALK1/Smad1 and TGF- $\beta 1 /$ ALK5/Smad2, are not isolated, they act together to provide feedback via Id1. It has been proposed that R-Smads exert their signal transduction effect through protein phosphorylation. Smad7 acts as a general inhibitor of the TGF- $\beta$ family, and inhibits TGF- $\beta 1$ signaling by preventing activation of $\mathrm{R}$ - and Co-Smads $(19,28,29)$. Moreover, ectopic Id1 overexpression is sufficient to overcome the inhibitory effects of Smad7 on HSC activation and $\alpha$-SMA fiber formation in vitro (23), which leads to aggravation of liver fibrosis.

HSCs are perisinusoidal cells in the subendothelial space between hepatocytes and sinusoidal endothelial cells, and are key in collagen accumulation (30). They can be identified by their vitamin A autofluorescence, perisinusoidal orientation, and expression of the cytoskeletal proteins desmin and $\alpha$-SMA. The present study showed that NIM811 suppressed $\alpha$-SMA protein expression in the adjacent sinusoids in $\mathrm{CCl}_{4}$-treated rats, which indicated that NIM811 decreased the extent of HSC activation in vivo, and that HSCs are one of the targets of NIM811. Therefore, HSCs were selected to conduct an in vitro study to confirm these in vivo results, which demonstrated that NIM811 inhibited TGF- $\beta 1$ and its downstream signaling molecules.

The results suggest another possible antifibrotic mechanism of NIM811, which inhibits the transcription of Smad1 and Id1, accompanied by a decrease in phospho-Smad1/5/8 
and Id1 protein expression. NIM811 can attenuate the fibrogenic signaling of HSCs by upregulating Smad7 expression. The results also showed that the TGF/1/ALK1/Smad1 pathway may represent a potential target for antifibrotic therapy. However, which components in the compound exhibit the inhibitory effects requires further investigation.

Fibrosis is caused by increased matrix production by HSCs and an increase in HSC numbers. It has been shown that NIM811 suppressed HSC proliferation, but not apoptosis in vitro (7). Platelet-derived growth factor (PDGF) is the most potent stellate cell mitogen identified thus far $(31,32)$. Downstream pathways of PDGF signaling have been carefully characterized in stellate cells, and induction of PDGF receptors early in stellate cell activation increases responsiveness to this potent mitogen (33-36). Therefore, our next study will investigate the effect of NIM811 on cultured HSCs isolated from $\mathrm{CCl}_{4}$-induced rats and the PDGF signaling pathway.

In conclusion, the results further implicate the involvement of the TGF $\beta 1 /$ ALK1/Smad1 and TGF- $\beta 1 /$ ALK5/Smad2 pathways during the development of hepatic fibrosis, and suggest that NIM811 may emerge as a novel option for hepatic fibrosis therapy through downregulation of the TGF- $\beta 1$ pathway.

\section{References}

1. Friedman SL: Mechanisms of hepatic fibrogenesis. Gastroenterology 134: 1655-1669, 2008.

2. Moreno $\mathrm{M}$ and Bataller R: Cytokines and renin-angiotensin system signaling in hepatic fibrosis. Clin Liver Dis 12: 825-852, 2008.

3. Gressner OA, Lahme B, Demirci I, Gressner AM and Weiskirchen R: Differential effects of TGF-beta on connective tissue growth factor (CTGF/CCN2) expression in hepatic stellate cells and hepatocytes. J Hepatol 47: 699-710, 2007.

4. Wynn TA: Cellular and molecular mechanisms of fibrosis. J Pathol 214: 199-210, 2008.

5. Parsons CJ, Takashima M and Rippe RA: Molecular mechanisms of hepatic fibrogenesis. J Gastroenterol Hepatol 22 (Suppl 1): S79-S84, 2007.

6. Casini A,Pinzani M, Milani S, Grappone C, Galli G, Jezequel AM, Schuppan D, Rotella CM and Surrenti C: Regulation of extracellular matrix synthesis by transforming growth factor beta 1 in human fat-storing cells. Gastroenterology 105: 245-253, 1993.

7. Kohjima M, Enjoji M, Higuchi N, Kotoh K, Kato M, Takayanagi R and Nakamuta M: NIM811, a nonimmunosuppressive cyclosporine analogue, suppresses collagen production and enhances collagenase activity in hepatic stellate cells. Liver Int 27: 1273-1281, 2007.

8. Waldmeier PC, Feldtrauer JJ, Qian T and Lemasters JJ: Inhibition of the mitochondrial permeability transition by the nonimmunosuppressive cyclosporin derivative NIM811. Mol Pharmacol 62: $22-29,2002$

9. Theruvath TP, Zhong Z, Pediaditakis P, Ramshesh VK, Currin RT, Tikunov A, Holmuhamedov E and Lemasters J: Minocycline and N-methyl-4-isoleucine cyclosporin (NIM811) mitigate storage/reperfusion injury after rat liver transplantation through suppression of the mitochondrial permeability transition. Hepatology 47: 236-246, 2008.

10. Zhong Z, Theruvath TP, Currin RT, Waldmeier PC and Lemasters JJ: NIM811, a mitochondrial permeability transition inhibitor, prevents mitochondrial depolarization in small-for-size rat liver grafts. Am J Transplant 7: 1103-1111, 2007.

11. Kohjima M, Enjoji M, Higuchi N, Kotoh K, Kato M, Takayanagi R and Nakamuta M: NIM811, a nonimmunosuppressive cyclosporine analogue, suppresses collagen production and enhances collagenase activity in hepatic stellate cells. Liver Int 27: 1273-1281, 2007

12. Wang H, Zhang Y, Wang T, You H and Jia J: N-methyl-4-isoleucine cyclosporine attenuates $\mathrm{CCl}$-induced liver fibrosis in rats by interacting with cyclophilin B and D. J Gastroenterol Hepatol 26: $558-567,2011$
13. Wang H, Zhang Y, Wang T, You Hand Jia J: N-methyl-4-isoleucine cyclosporine attenuates $\mathrm{CCl}$-induced liver fibrosis in rats by interacting with cyclophilin B and D. J Gastroenterol Hepatol 26: 558-567, 2011.

14. Dooley S, Delvoux B, Lahme B, Mangasser-Stephan K and Gressner AM: Modulation of transforming growth factor beta response and signaling during transdifferentiation of rat hepatic stellate cells to myofibroblasts. Hepatology 31: 1094-1106, 2000.

15. Friedman SL: Hepatic fibrosis-overview. Toxicology 254: 120-129, 2008.

16. Breitkopf K, Godoy P, Ciuclan L, Singer MV and Dooley S: TGF-beta/Smad signaling in the injured liver. Z Gastroenterol 44: 57-66, 2006.

17. Border WA and Noble NA: Transforming growth factor beta in tissue fibrosis. N Engl J Med 331: 1286-1292, 1994.

18. Kolodziejczyk SM and Hall BK: Signal transduction and TGF-beta superfamily receptors. Biochem Cell Biol 74: 299-314, 1996.

19. Miyazawa K, Shinozaki M, Hara T, Furuya T and Miyazono K: Two major Smad pathways in TGF-beta superfamily signalling. Genes Cells 7: 1191-1204, 2002.

20. Attisano L and Wrana JL: Signal transduction by the TGF-beta superfamily. Science 296: 1646-1647, 2002.

21. Higashiyama R, Inagaki Y, Hong YY, Kushida M, Nakao S, Niioka M, Watanabe T, Okano H, Matsuzaki Y, Shiota G and Okazaki I: Bone marrow-derived cells express matrix metalloproteinases and contribute to regression of liver fibrosis in mice. Hepatology 45: 213-222, 2007.

22. Inagaki Y and Okazaki I: Emerging insights into transforming growth factor beta Smad signal in hepatic fibrogenesis. Gut 56: 284-292, 2007.

23. Wiercinska E, Wickert L, Denecke B, Said HM, Hamzavi J, Gressner AM, Thorikay M, ten Dijke P, Mertens PR, Breitkopf Ka and Dooley S: Id1 is a critical mediator in TGF-beta-induced transdifferentiation of rat hepatic stellate cells. Hepatology 43: 1032-1041, 2006.

24. Miyazono K, Kusanagi K and Inoue H: Divergence and convergence of TGF-beta/BMP signaling. J Cell Physiol 187: 265-276, 2001

25. Friedman SL, Yamasaki G and Wong L: Modulation of transforming growth factor beta receptors of rat lipocytes during the hepatic wound healing response. Enhanced binding and reduced gene expression accompany cellular activation in culture and in vivo. J Biol Chem 269: 10551-10558, 1994.

26. Zebedee $\mathrm{Z}$ and Hara E: Id proteins in cell cycle control and cellular senescence. Oncogene 20: 8317-8325, 2001.

27. Li L, Zhao XY and Wang BE: Down-regulation of transforming growth factor beta 1/activin receptor-like kinase 1 pathway gene expression by herbal compound 861 is related to deactivation of LX-2 cells. World J Gastroenterol 14: 2894-2899, 2008.

28. Itoh S, Itoh F, Goumans MJ and Ten Dijke P: Signaling of transforming growth factor-beta family members through Smad proteins. Eur J Biochem 267: 6954-6967, 2000.

29. Itóh S, Landström M, Hermansson A, Itoh F, Heldin $\mathrm{CH}$, Heldin NE and ten Dijke P: Transforming growth factor beta1 induces nuclear export of inhibitory Smad7. J Biol Chem 273: 29195-29201, 1998.

30. Friedman SL: Hepatic stellate cells: Protean, multifunctional and enigmatic cells of the liver. Physiol Rev 88: 125-172, 2008.

31. Pinzani M: PDGF and signal transduction in hepatic stellate cells. Front Biosci 7: d1720-d1726, 2002.

32. Borkham-Kamphorst E, van Roeyen CR, Ostendorf T, Floege J, Gressner AM and Weiskirchen R: Pro-fibrogenic potential of PDGF-D in liver fibrosis. J Hepatol 46: 1064-1074, 2007.

33. Pinzani M and Marra F: Cytokine receptors and signaling in hepatic stellate cells. Semin Liver Dis 21: 397-416, 2001.

34. Lechuga CG, Hernandez-Nazara ZH, Hernández E, Bustamante M, Desierto G, Cotty A, Dharker N, Choe M and Rojkind M: PI3K is involved in PDGF-beta receptor upregulation post-PDGF-BB treatment in mouse HSC. Am J Physiol Gastrointest Liver Physiol 291: G1051-G1061, 2006.

35. Harder KW, Owen P, Wong LK, Aebersold R, Clark-Lewis I and Jirik FR: Characterization and kinetic analysis of the intracellular domain of human protein tyrosine phosphatase beta (HPTP beta) using synthetic phosphopeptides. Biochem J 298: 395-401, 1994.

36. Wong L, Yamasaki G, Johnson RJ and Friedman SL: Induction of beta-platelet-derived growth factor receptor in rat hepatic lipocytes during cellular activation in vivo and in culture. J Clin Invest 94: 1563-1569, 1994. 